Vol. 6, No. 2, 2019

https://doi.org/10.23939/eem2019.02.032

UDC 164.01

JEL Classification Code C51, F 15, L11

Ye. Krykavskyy

Lviv Polytechnic National University, Ukraine, Doctor, Professor

ORCID: 0000-0002-1847-586X

N. Fihun

Lviv Polytechnic National University, Ukraine, Associate Professor

S. Nycz-Wojtan

Vistula University, Warsaw, Mgr., Ph.D student

ORCID: 0000-0002-2350-7328

\title{
THE DEPENDENCE OF CHINA BELT \\ AND ROAD INITIATIVE EFFICIENCY TO THE LEVEL OF LOGISTICS INFRASTRUCTURE DEVELOPMENT
}

\begin{abstract}
Annotation. The article analyzes the peculiarities of the impact of logistics infrastructure on the effectiveness of project implementation. The role of LPI as an indicator of infrastructure development, investment opportunities and its peculiarities are highlighted. The regional peculiarity of logistics development with the help of LPI is outlined. Abilities for Belt and Road initiative where analyzed and emphasized the status of logistics practice in the Asian countries, which are involved into the project. Analyzed the peculiarities of formation of international and domestic LPI, their differences in creation, as well as factors considered for statistics bases. Key opportunities for the development of the BRI project and the prerequisites for its creation have been identified. Distinguished input and output indicators of the LPI in to the two types: areas for policy regulations (inputs) and service delivery performance outcomes. Formed the basic factors which need to be taken into consideration during the decision making for investments into the logistics infrastructure of BRI project. Infrastructural improvements that have already been implemented or are being finalized were highlighted. The key risk factors in project implementation are highlighted, with opportunities to consider and offset their impact on the final implementation of the project.

Key words: Logistics, Logistics Performance Index (LPI), Supply chains, China Belt and road initiative, New Silk Road.
\end{abstract}

\section{Formulation of the problem}

Logistics is the basis for the efficient formation of flows, the way to create correct protocols in the management of materials, information, people and finance. Logistics creates a significant basis for sustainable development. The processes built on the logistic principles allows to increase the potential of the development of international activity, since they are immediately guided by international standards. Given the opportunities that businesses now receive through the Internet, namely:

- International cooperation is simplified, and access to international markets depends more on the ease of doing business in a particular country, and not from the locally competitive enterprise itself.

- With information on international standards, borderline rules, tax characteristics, a company can often adapt its activities to a specific customerpartner.

- the preconditions for the formation of databases are created, and their effective application in the course of consulting clients of the enterprise in an online mode with any localization (language, time of service, the ability to react locally, etc.); 
The dependence of china belt and road initiative efficiency to the level of logistics...

- the possibilities for intermodal transportation are increased, since the document circulation is simplified between elements of logistic chain;

- Increasing trust between partners through effective communication;

The restrictions on its activities could be created usually locally. It is possible to formulate plans globally, and only due to the ability to find relevant information, its elaboration and rapid implementation at the enterprise provides high competitiveness and growth potential.

Logistics capabilities depend on readiness for change and adaptation to new environmental rules. Logistics in the framework of the project of the new silk road proposed by China is a critical factor in the quality of which the whole project will depend.

Logistic is the main element of optimization. Which enterprise will be ready for changes proposed by the market - those will survive. Supply chains are only as good as their weakest link. That's why the analysis of Logistics infrastructure is critical for evaluation of main bottlenecks and possibilities of Belt and Road initiative.

\section{Analysis of recent research and publications.}

The problem of logistics infrastructure in general and the BRI project in particular is being investigated by many scientists. In particular, Hübner W. [1, 2] explores the ideas of the Silk Road in the new paradigm of the world economy. Bożyk P. $[3,4]$ analyzes international economic relations, including the impact of the development of the BRI project on them.Prof. Krykavsky [5] explores the logistical features of the development of national infrastructures, the impact of LPI on investment attractiveness.

\section{Problem statement of the article.}

Logistics is very complex issue. It includes beyond transportation - warehousing and storage, terminal operations, customs brokerage, information exchange between countries, corporations or independent entrepreneurs, procedures which helps to cover conditions of products sent. Totally, the costs of end products on average covers usually up to $30 \%$ of costs for logistics operations. The Logistics Performance Index helps countries in general and enterprises individually get better competitive conditions on the global market by good
LPI marks, give "green light" for investors to work with those companies. More similar LPI are between countries or enterprises - better possibilities for integration and collaboration.

The Belt and Road Initiative brings together a large number of countries whose level of development is quite different. It should be noted that, as a rule, improvements made in countries with lower GDP per capita produce more overall economic benefits than in more developed countries. The best level of logistics contributes to the development of trade, quality of services and attracts investors. One of the key elements of logistics that critically affects the performance of business entities is the ability of customs: the speed of goods documentary paperwork, goods verification, the ability to work with a unpredicted increase in demand for checkpoints, available infrastructure, etc. The World Bank says that: "better logistics have a greater effect on trade promotion than tariff cuts: Logistics costs influence trade costs more than tariff barriers in most countries" [6].

In addition, logistical flow management capabilities and the transparency of their movement control allow companies to form more openly global supply chains. The number of options are opening for optimizing production processes, optimizing costs, developing products, their assembly, manufacturing of spare parts, selecting partners, choosing options for delivering goods, and finally increasing the level of customer service at the final stage of service.

The Logistics Performance Index (LPI) is a complex indicator of countries infrastructure status based on logistics performance. The LPI is calculated on a survey of global freight forwarders and express carriers about pros and cons of local logistics where they operate. Generally, we can distinguish LPI from two perspectives - domestic and international. The main difference between them are:

1) Domestic LPI is a result of local logistics experts survey. It contains information regarding logistics infrastructure, availability of logistics services, level of legal control, possibilities of multimodal delivery, the costs and safety of transportation. 
2) International LPI gives information from trading partners which are operating based in other countries. This kind of information gives real overview of the status of countries LPI. International LPI methodology contains procedure which requires analysis of six main elements of logistics in the country. That main elements are following [7]:

1. Efficiency of clearance processes (e.g. customs, ports, railway and airports);

2. Logistics-related infrastructure;

3. Ease of arranging competitively priced international shipments ("International shipments");
4. Competence and quality of logistics services;

5. Ability to track and trace consignments;

6. Timeliness of delivery.

In general, for evaluation of LPI take into account answers from logistics professionals to the questions covers 6 mentioned areas of work. Respondent answers questions only regarding countries where they had experience of work (experts provide rates for up to 8 countries), but it is forbidden to rate own country where operates expert. The International LPI's core components are depicted on the figure 1.

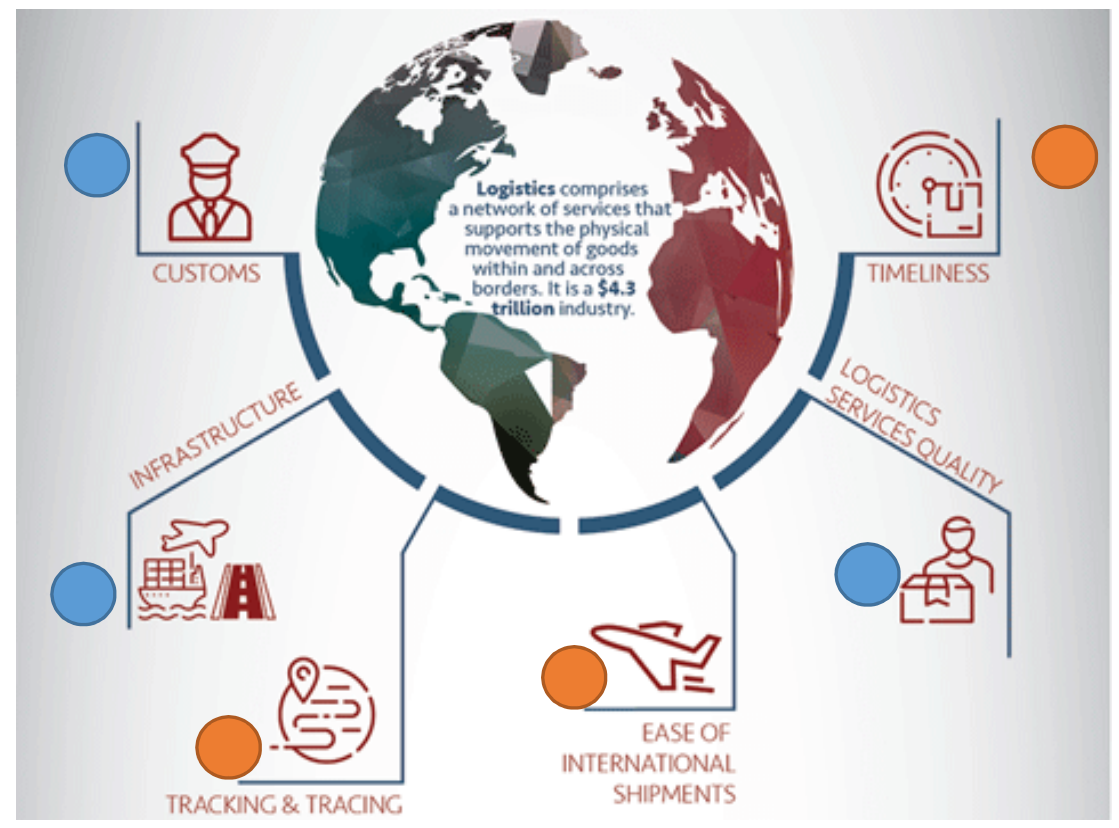

$\begin{array}{ll}\text { - } & \text { Areas for policy regulations (inputs) } \\ \text { - } & \text { Service delivery performance outcomes }\end{array}$

Fig. 1. Input and output indicators of the LPI

The eight countries are chosen based on the most important export and import markets of the country where the respondent is located [8]. The analysis of LPI countries indicators shows that customs, infrastructure and logistics services quality belong to the area of policy regulations, and indicates what kind of rules for operation activities in the country exist. Those regulations are almost uncontrolled by single operator and could be improved by a complex of actions of countries government. Other three indicators: timeliness, tracking and tracing and ease of international shipments related to the supply chain performance, and are more manageable by companies. It shows the countries culture of logistics and gives opportunities for prediction of effectiveness for future improvements of logistics services in the country.

In the case when some LPI indicators are over-interpreted in the analyzed period of time, the countries score should be considered in the bigger time scale (for a couple of years, which will shows overall countries logistics performance) [7].

However, it is also necessary to take into account that the level of logistics infrastructure is usually different within one country. And with 


\section{The dependence of china belt and road initiative efficiency to the level of logistics...}

certain regions that have significant business activity, the country's overall logistics performance index may increase. This factor also poses the risks of correctly predicting the implementation of the new silk route. For example, China has an extremely well-developed infrastructure of southern coastal areas as well as infrastructure in large cities. In contrast, the northwestern part of China lags far behind in the development of logistics infrastructure, availability of skilled staff etc. In such a situation, when planning the project implementation, guided by the logistic efficiency index, it is necessary to take into account the possibilities of specific regions, where it is planned to introduce new objects or reconstruct old ones.

\section{Outline of the main material of the article.}

Based on the description of policy research working paper by Julia Bird "Reshaping Economic Geography in Central Asia" (2019) the Belt and Road Initiative (BRI) is a project that seeks to foster improved connectivity between China and the rest of Asia, the Middle East and on to Africa and Europe. The initiative, launched in 2013, encompasses more than 65 countries, representing over 62 percent of the world's population; the potential scope for economic transformation is large. However, the benefits of building new infrastructure for every country affected by the initiative are highly uncertain, and the spatial incidence of effects may vary widely within each country. Building roads and railway links and reducing times crossing the borders can facilitate trade, but the growth of industry in some regions may be at more expensive level than in others regions [9, p. 2].

The implementation of the project by China aims to increase trade with Europe and within Asia, as well as to increase geopolitical influence in those areas where China is investing. It should also be noted that the implementation of infrastructure is very often the responsibility of experts from China. This approach is a type of protectionism, since it implies full control of the Chinese side on the project implementation, provides the ability to appoint management from its own experts, employs a significant number of people, and generates additional opportunities to cooperate on better terms with local businesses. The BRI project is largescale, long-lasting and a bridgehead for the development of more stable and flexible logistics chains for China.
Analyzing the scope of works that needed for successful launch of initiative it could be summarized that there are big number of risks which could be controlled by initiators but for that need should be the same willingness from each of the partner. The biggest problem of any system is its heterogeneity. The reason for this is, first of all, difficulties with planning, predicting needs in the middle of the ecosystem, correct risk assessment, planning the volume of necessary resources, etc. Analyzing the planned silk road (not taking into account its different routes) we can speak of an initiative, as the formation of a highly complex logistic chain, which combines different levels of infrastructure development, approaches to the organization of work, weather conditions, and the mentality of the country, which is appropriate should be identified as elements of the logistics chain.

Logistics infrastructure within BRI is not perfect and that is why to predict risks and gain winwin situation for all partners of the BRI its needed to provide detailed analysis of countries LPI within main planned routs.

Countries participating in the BRI project have significant differences in the level of logistics infrastructure, in particular in the areas related to trade, goods movement, transport, and material security. In general, if we analyze Fig. 2. the quality of trade and transport-related infrastructure can be argued that the differentiation is extremely high. For example, the participants of the project are Singapore, whose LPI index is higher than the European countries, and given the small geographical length of the country, and its "homogeneity" in relation to the level of development - this indicator objectively points to the whole picture of this partner in the project. In the Chinese situation, as noted previously, the index is 3.75 out of 5 , which is one of the highest among the project partners, but geographically, the quality of trade and logistics infrastructure is not sufficient in the northeast to fully meet the project's BRI needs.

Accordingly, the volume of investments will be significantly different compared to other regions of the country. In general, there is a significant correlation between the LPI index and the level of logistics development in the countries. For example, indicators from Afghanistan, Bhutan and Iraq, Ukraine which are approaching the 1.81, 1.91, 2.03, 2.22 accordingly (one of the lowest level among BRI participants in the project), indicate a significant gap in logistics performance compared to 


\section{Ye. Krykavskyy, N. Fihun, S. Nycz-Wojtan}

LPI leaders. At the same time, the analysis of economic development in general and GDP per capita in particular points to paltry differences in the welfare of the population within the country. To sum up, in the BRI project involved countries that are world leaders in logistics efficiency and countries with some of the lowest LPI rates. This fact confirms that one of the most risky factors in the way of BRI project implementation is a significant logistical differentiation, which also causes significant risks in logistic processes locally.
It should also be noted that apart from the LPI factor, which indicates the experience of counterparties with the country's logistics infrastructure, it is important to understand the status of key infrastructure entities that will be involved as logistics hubs and key facilities in the BRI project. Table 1 show the results of the survey on the quality of ports, roads, railways and airports of the BRI members [7]: 100 - very low quality, 0 - good quality. In the table indicated part of the countries, which will participate in the BRI project.

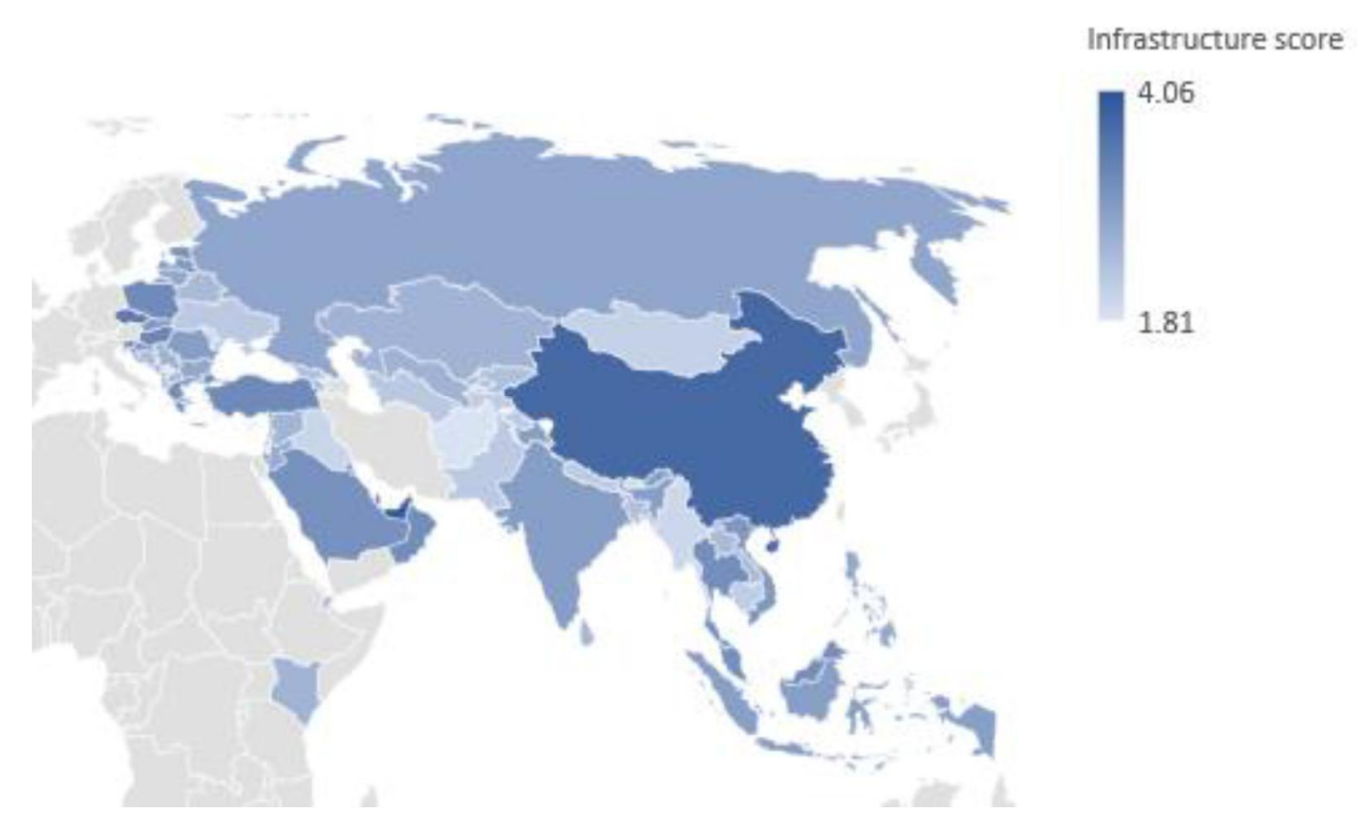

Fig. 2. Quality of trade- and transport-related infrastructure of BRI economies; Source: International LPI 201812

Table 1

Quality of key logistics infrastructure elements of BRI project countries

\begin{tabular}{|c|c|c|c|c|}
\hline \multirow{2}{*}{ Country } & \multicolumn{4}{|c|}{ Infrastructure } \\
\hline & Port & Airport & Railway & Road \\
\hline Indonesia & 83 & 67 & 80 & 83 \\
\hline Russian Federation & 50 & 50 & 50 & 75 \\
\hline Vietnam & 40 & 30 & $\mathrm{n} / \mathrm{a}$ & 60 \\
\hline India & 23 & 18 & 26 & 48 \\
\hline Uzbekistan & 20 & 20 & 40 & 20 \\
\hline Saudi Arabia & 20 & 11 & 63 & 10 \\
\hline Turkey & 15 & 13 & 50 & 15 \\
\hline Greece & 14 & 14 & 77 & 36 \\
\hline China & 0 & 0 & 9 & 18 \\
\hline Singapore & 0 & 0 & 17 & 0 \\
\hline Poland & 0 & 33 & 50 & 0 \\
\hline
\end{tabular}

Source: improved by author based on [7] 
The analysis of the data presented in Table 1 leads to the conclusion of the heterogeneity of the development of key infrastructural elements, which on the one hand is a negative factor, on the other, this information allows us to more correctly form the vectors for the development of the infrastructure of the regions where the routes of the new Silk Road will pass. It should also be noted that the quality of roads in contrast to railways is in a worse state, which also indicates the problem of flexibility and adaptability in the formation of logistics flows in the future, as road transport is the most flexible way to delivery, especially geographically in difficult areas.

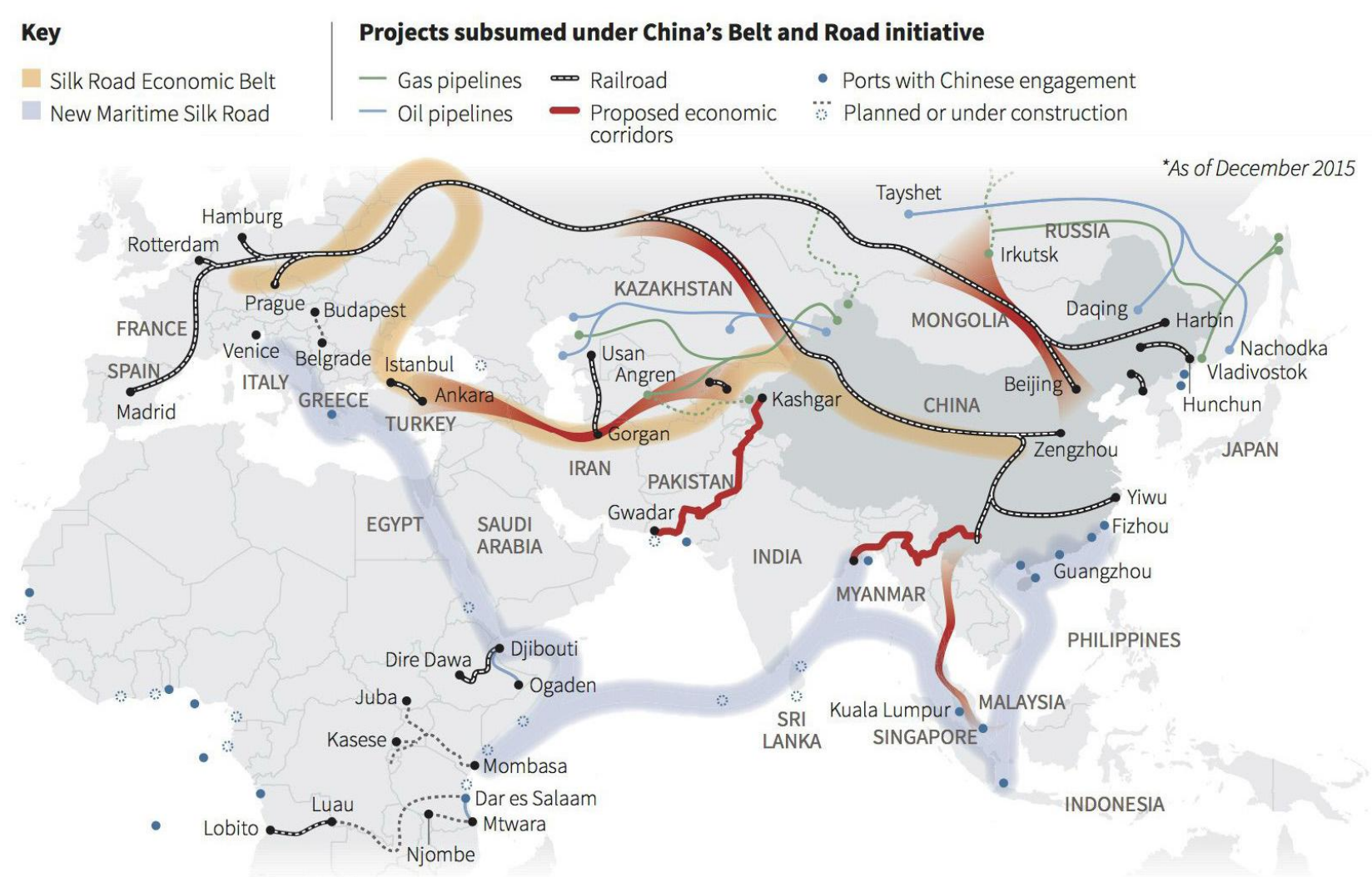

Source: [10]

Fig. 3. New Silk road routes under the BRI project

On the figure 3 depicted routes which are planned to be constructed under the BRI project. As can be seen from the figure 3, a large part of the routes pass through countries where there are armed conflicts, and therefore the risks of security of logistics along the respective routes increase. In addition, there is a risk of confidence of economic entities in the organization of supplies in precisely these areas. The risks can be considerable, and therefore in the process of infrastructure formation, besides the harmonization of logistic infrastructure, it is necessary to create conditions for the security of movement of material flows. Anyway currently most efforts are aimed at building the necessary infrastructure, which creates a certain level of skepticism in potential counterparties while promoting the idea of implementing a new silk route.

The process of product creation, parts manufacturing, delivery of replacement parts, components, assembly of complex products requires the ability to move goods quickly, reliably and at low cost. A particular bottleneck in this situation is the borders and the increased control of goods in connection with the presence of conflicts. The BRI economies that would benefit most from infrastructure investment (based on their LPI level) are Bhutan, Afghanistan, Moldova, Iraq, Mongolia, Yemen, Cambodia, Tajikistan, Nepal, Pakistan and Ukraine. Investing in railways (as one of the safest 


\section{Ye. Krykavskyy, N. Fihun, S. Nycz-Wojtan}

and cheapest modes of transport) is an important argument for ensuring regional development. In addition, it is advisable to develop the infrastructure of roads, highways for fast transportation to inaccessible (for other modes of transport) places. Port development is also an important element of diversification of supply routes, cheaper and also keeping the pricing policy at a very flexible level when there is variability in cargo delivery options. In the figure 4 depicted areas where was made transport improvements under the BRI project.

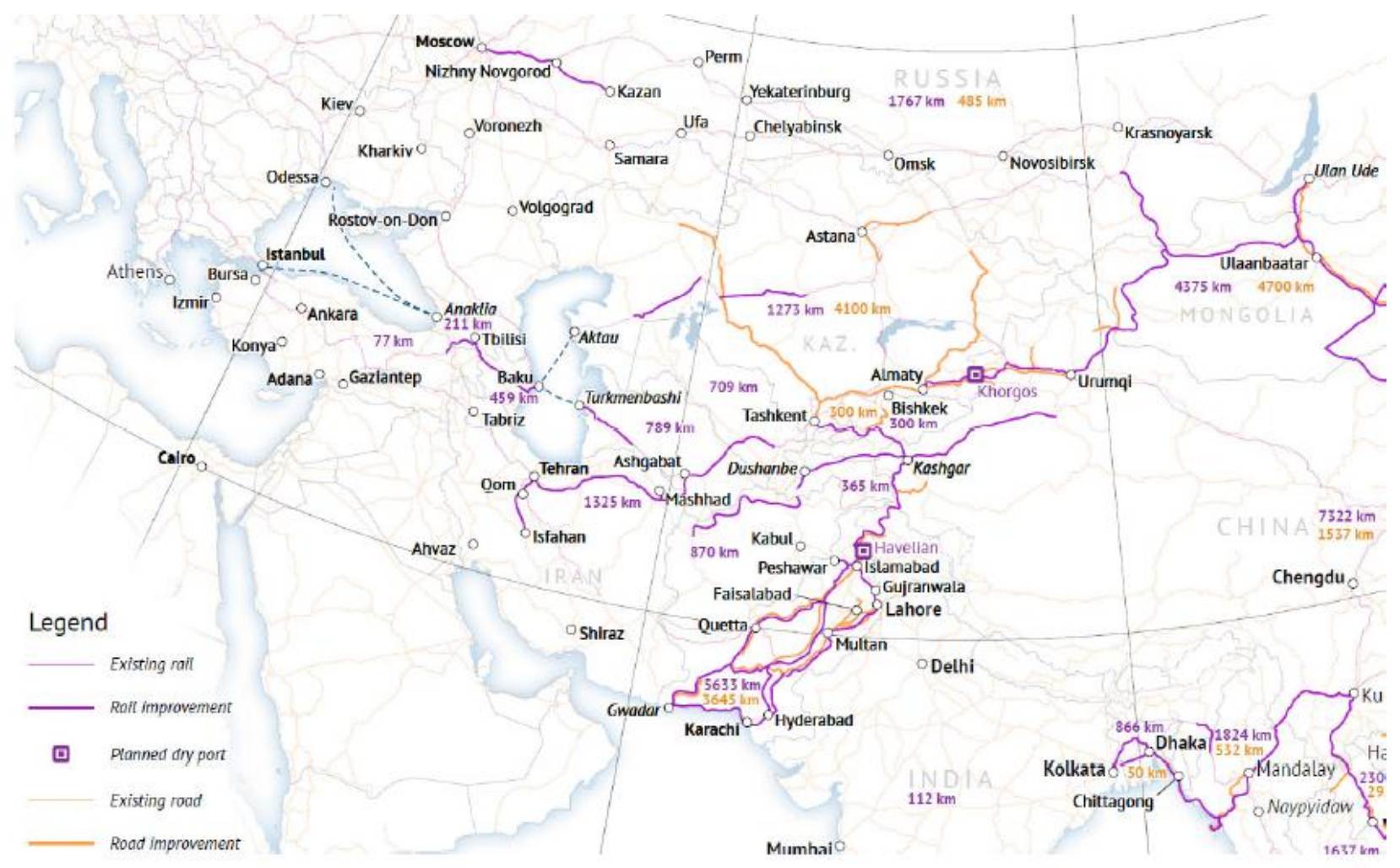

Fig. 4. Map of Transport Improvements under the BRI.

Source: [9]

The scale of infrastructure change, as can be seen from Figure 4, is very large. Improvements are of a local nature at the moment, in which it is impossible to talk about the possibilities of networking and securing the first deliveries to Europe. However, testing the capabilities of routes, their bottlenecks, and identifying risks is what experts are currently working on.

In general, there are a number of risks that could potentially be identified or encountered by partners in the development of the necessary infrastructure $[11,12]$ :

1) political instability in the region;

2) customs procedures, instructions, restrictions are very important in the BRI project area;
3) in some countries, there are international sanctions, restrictions on investment, restrictions on the activities of international companies, which in turn also reduces the possibility of attracting business activities in these regions;

4) weak development of transport infrastructure;

5) lack of professional staff;

6) difficulties in attracting foreign specialists, in particular because of low pay and language barriers;

7) the level of LPI in the BRI countries of the project is very different, which creates different levels of infrastructure tasks, which in turn increases the cost of project implementationo possibilities to plan and execute project strategy; 
The dependence of china belt and road initiative efficiency to the level of logistics...

8) within the BRI project, countries with the highest level of LPI and at the same time one of the lowest levels are involved. This fact points to the problem of heterogeneity of logistical tasks, different level of influence of infrastructure improvements on the economy of regions;

9) the level of infrastructure development within one country is very uneven. Yes, China's northeast and south have good LPIs, but the northwest and central China have significant infrastructure problems. This fact raises the problem of development of the land route of the project;

10) corruption in some countries of the project is very high. This creates infrastructure risks, security of supply chains and corresponding investment opportunities;

11) the qualification and quality of railway service providers is lower than the quality and qualification of road and maritime service providers, despite the greater development of railway infrastructure;

12) the scale of the project raises a number of environmental and social problems. Thus, the development of infrastructural facilities provokes an increase in deforestation, the creation of dams or the laying of roads in green areas. In the context of social problems, the growth of local business activity increases migration flows. Opportunities for mobility are increasing on a large scale, which is also a difficult controlled and not always positive process for the economies of the less industrialized regions [13];

13) low-GDP countries' commitment to developing their own infrastructure under the BRI project raises the problem of increasing debt obligations to creditors, investment banks etc $[14,15]$.

\section{Conclusions}

Notwithstanding the risks listed in the implementation of the BRI project, China's initiative on a new silk route is a positive project. Of course, the biggest goal of the project initiator - China is to increase its economic growth and spread Chinese products in Europe and around the world, reduce the level of influence of the US and its neighbors on maritime supply chains, as well as increase the areas of influence in countries where infrastructural transformations occur. , because very often it is the Chinese specialists who manage the implementation of infrastructure change. However, on the other hand, China's commitments are also the highest. The risks involved are significant and, if the project is implemented, the Asian countries will be able to stabilize the political situation, establish greater cooperation and overcome the low standard of living of the majority of the region's population.

\section{References}

1. Hübner, W., Rybicka, M., Wieszczycka, W. (2016). Liderzy Azji i tradycje Szlaku Jedwabnego w nowej architekturze świata, (w:) Hübner W. (red.), Azja XXI wieku i renesans Szlaku Jedwabnego. Tradycja ksztattująca przyszłość, Wydawnictwo Akademii Finansów i Biznesu Vistula, Warszawa;

2. Hübner, W., Rybicka, M., Wieszczycka, W. (2017a). Nowy Szlak Jedwabny - różne perspektywy narodowe i różne cele do pogodzenia, (w:) Polityka gospodarcza Polski $w$ integrujacej się Europie 2016-2018, Instytut Badań Rynku, Konsumpcji i Koniunktur, Warszawa.

3. Boży, P. (2008), Międzynarodowe stosunki ekonomiczne, Polskie Wydawnictwo Ekonomiczne, Warszawa;

4. Boży, P., Misala, J., Puławski, M. (2002). Międzynarodowe stosunki ekonomiczne, PWE, Warszawa;

5. Krykavskyi, Y. V. \& Yakymyshyn, L. Ya. (2018). Komplementarnist stratehii marketynhu ta lohistyky $v$ lantsiuhu postavok tovariv povsiakdennoho popytu [Complexity of marketing and logistics strategies in the supply chain of fast moving consumer goods] Marketynh i tsyfrovi tekhnolohii Marketing and Digital Technologies, 2(1), 21-32.

6. Connectivity, Logistics \& Trade Facilitation. World Bank, 2019. Retrieved from: https://www.worldbank.org/en/topic/tradefacilitation-and-logistics;

7. Christina Wiederer Logistics Infrastructure Along the Belt and Road Initiative Economies. MTI Practice Notes, World Bank, 2018. Retrieved from: http://documents.worldbank.org/curated/en/25956 1545148936579/pdf/133058-MTI-Practice-Note-5Final.pdf;

8. Connecting to Compete 2014 Trade Logistics in the Global Economy. Retrieved from: https://wb- 
Ye. Krykavskyy, N. Fihun, S. Nycz-Wojtan

lpi-media.s3.amazonaws.com/LPI \%20

Methodology.pdf;

9. Bird Julia, The Belt and Road Initiative: Reshaping Economic Geography in Central Asia? Social, Urban, Rural and Resilience Global Practice, World Bank, April 2019. Retrieved from: http://documents. worldbank.org/curated/en/836301554729486900/ pdf/The-Belt-and-Road-Initiative-ReshapingEconomic-Geography-in-Central-Asia.pdf;

10. China Belt and Road Initiative: Measuring the impact of improving transport connectivity on international trade in the region - a proof-ofconcept study. RAND Corporation 2018, Retrieved from: https://www.rand.org/content/ dam/rand/pubs/research_reports/RR2600/RR2625/

RAND_RR2625.pdf;

Aggregated LPI 2012-2018. Retrieved from: https://lpi.worldbank.org/international/aggregated -ranking;
12. Elizabeth Losos, Is a Green Belt and Road feasible? How to mitigate the environmental risk of BRI Infrastructure Project. Retrieved from:https://blogs. worldbank.org/trade/green-belt-and-road-feasiblehow-mitigate-environmental-risk-briinfrastructure-project;

13. Indermit Gill, Winners and losers along China's Belt and Road. Retrieved from: https://www.brookings. edu/blog/future-development/2019/06/21/winnersand-losers-along-chinas-belt-and-road;

14. Michele Ruta, How much will the Belt and Road Initiative reduce trade costs? Retrieved from:https://blogs.worldbank.org/trade/how-muchwill-belt-and-road-initiative-reduce-trade-costs;

15. Belt and Road Economics, Opportunities and risks of transport corridors. International Bank for Reconstruction and Development, The World Bank, 2019, Retrieved from: https://openknowledge. worldbank.org/bitstream/handle/10986/31878/978 1464813924.pdf. 